\title{
SISTEM PENDUKUNG KEPUTUSAN DALAM PEMILIHAN PROVIDER INTERNET UNTUK MENUNJANG PERKULIAHAN ONLINE DI MASA PANDEMI COVID-19
}

\section{DECISION SUPPORT SYSTEM IN THE SELECTION OF INTERNET PROVIDER TO SUPPORT ONLINE LEARNING IN THE COVID-19 PANDEMIC}

\author{
Hartomo Briantama ${ }^{1}$, Lia Mazia ${ }^{2}$, Lilyani Asri Utami ${ }^{3}$ \\ Teknologi Informasi, Program Studi Sistem Informasi \\ Universitas Nusa Mandiri \\ Email: lilyani.lau@nusamandiri.ac.id
}

\begin{abstract}
Abstrak
Pandemi Covid-19 telah mengubah metode pembelajaran perkuliahan yang awalnya tatap muka menjadi perkuliahan jarak jauh atau daring. Banyak kriteria yang menjadi pertimbangan mahasiswa dalam memilih provider internet untuk menunjang perkuliahan online. Penelitian ini bertujuan untuk memecahkan permasalahan serta mencari solusi untuk mahasiswa Universitas Nusa Mandiri dalam memilih provider internet yang sesuai dengan kebutuhan guna mendukung kegiatan perkuliahan online di masa pandemi Covid-19. Sistem Pendukung Keputusan menggunakan metode Analytical Hierarchy Process (AHP) dilakukan peneliti dalam memilih provider internet berdasarkan kriteria dan alternatif yang ditentukan. Kriterianya terdiri dari harga, bandwith, cakupan area jaringan, dan support helpdesk. Sedangkan alternatif terdiri dari Indihome, Biznet, FirstMedia, dan My Republic. Berdasarkan perhitungan AHP, cakupan area jaringan menjadi prioritas pemilihan provider internet. Hasil akhir dari perhitungan dijelaskan bahwa provider internet Indihome sebagai penyedia layanan internet lebih unggul dari alternatif lainnya dengan nilai 0,3712 dan tingkat presentase 37\%. Indihome lebih memenuhi kriteria pemilihan provider internet sebagai penunjang kegiatan kuliah online. Penerapan sistem penunjang keputusan ini dapat memberikan rekomendasi bagi mahasiswa untuk menentukan atau memilih provider internet yang akan digunakan untuk menunjang perkuliahan online di masa pandemi Covid-19.
\end{abstract}

Kata Kunci: Analytical Hierarchy Process (AHP), Provider, Internet, Sistem Pendukung Keputusan.

\begin{abstract}
The Covid-19 pandemic has changed lecture learning methods from face-to-face to distance learning or online. Students consider many criteria in choosing an internet provider to support online lectures. This study aims to solve problems and find solutions for Nusa Mandiri University students in selecting an internet provider that suits their needs to support online lecture activities during the Covid-19 pandemic. Decision Support System using the Analytical Hierarchy Process (AHP) method is carried out by researchers in selecting internet providers based on predetermined criteria and alternatives. The requirements consist of price, bandwidth, network area coverage, and helpdesk support. At the same time
\end{abstract}


the other opinion consist of Indihome, Biznet, FirstMedia, and My Republic. Based on AHP's calculation, network coverage area becomes the priority for internet provider selection. The final result of the calculation explains that the Indihome internet provider as an internet service provider is superior to other alternatives with a value of 0.3712 and a percentage rate of 37\%. Indihome better meets the criteria for selecting an internet provider as a support for online college activities. The application of this decision support system can provide recommendations for students to determine or select an internet provider that will be used to support online lectures during the Covid-19 pandemic.

Keywords: Analytical Hierarchy Process (AHP), Provider, Internet, Decision Support System.

\section{PENDAHULUAN}

Pandemi Covid-19 berimbas ke semua sektor tak terkecuali sektor pendidikan di Indonesia. Sesuai Surat Edaran Kemendikbud Nomor 15 Tahun 2020 tentang Pedoman Penyelenggaraan Belajar Dari Rumah Dalam Masa Darurat Penyebaran Covid-19 menyebutkan bahwa metode dan media pelaksanaan belajar di rumah dilaksanakan dengan pembelajaran jarak jauh yang dibagi ke dalam dua pendekatan yaitu pembelajaran jarak jauh dalam jaringan (daring) dan luar jaringan (luring).

Dengan kebijakan yang mengharuskan pelajar dan mahasiswa belajar di rumah internet adalah salah satu teknologi informasi yang sangat dibutuhkan untuk menunjang kegiatan pembelajaran jarak jauh. Kebutuhan koneksi internet saat ini bukan hanya menjadi pelengkap namun sudah menjadi kebutuhan yang wajib ada untuk kehidupan sehari-hari. Dengan akses internet, membuat masyarakat terutama mahasiswa tetap dapat melakukan aktifitas pembelajaran tanpa melalukan tatap muka. Maka dari itu internet sangat dibutuhkan untuk menunjang kegiatan pembelajaran saat pandemi seperti sekarang ini. Dalam hal ini ditemukan beberapa kendala bagi pelajar dalam hal ini mahasiswa saat pembelajaran daring atau kuliah online, salah satunya kuota internet yang terbatas dan sebagian besar pelajar masih mengandalkan paket data pribadi atau tethering untuk mengakses pembelajaran daring, yang seperti kita tahu bahwa penggunakan tethering hotspot boros dan kurang efisien. Saat ini banyak provider penyelenggara jasa provider internet yang menawarkan paket bandwidth besar dengan pilihan harga yang bervariasi, membuat masyarakat dalam hal ini sebagai mahasiswa memiliki pertimbangan dalam memilih provider internet yang tepat.

Berdasarkan permasalahan di atas dapat diusulkan metode penunjang pengambilan keputusan yang dapat memberikan alternatif keputusan dalam memilih provider internet dengan metode Analitycal Hierarchy Process (AHP). AHP pertama kali dikembangkan oleh Thomas L. Saaty dengan cara menguraikan masalah multi kriteria yang kompleks menjadi suatu hierarki. Hierarki merepresentasikan sebuah permasalahan yang kompleks dalam suatu struktur multilevel. Level pertama yaitu tujuan, level selanjutnya yaitu faktor, kriteria, sub kriteria, hingga level terakhir dari alternatif [1]. 


\section{LANDASAN TEORI}

Dalam penyusunan penelitian ini, penulis menggunakan beberapa teori sebagai landasan.

\section{A. Internet}

Internet didefinisikan sebagai dua komputer atau lebih yang memiliki konektivitas membentuk jaringan komputer hingga meliputi jutaan komputer didunia secara global (internasional) yang saling berinteraksi dan bertukar pikiran [2]. Internet atau Interconnected Network menghubungkan antar komputer secara global dalam sebuah jaringan komputer [3].

\section{B. Internet Service Provider (ISP)}

Internet Service Provider (ISP) merupakan perusahaan atau badan yang menyediakan jasa akses internet dan pelayanan yang berhubungan dengan dunia internet [4]. ISP, juga dikenal sebagai ISP, adalah organisasi yang menyediakan layanan koneksi Internet ke klien fisik dan korporat. [5]. Internet Service Provider adalah perusahaan penyedia layanan internet [6].

\section{Sistem Pendukung Keputusan}

Sistem pendukung keputusan adalah sistem yang membantu pengambil keputusan dengan menyediakan mereka dengan informasi yang diproses yang relevan dan diperlukan untuk membuat keputusan yang lebih cepat dan lebih akurat tentang masalah. Oleh karena itu, sistem ini tidak dimaksudkan untuk mengubah proses pengambilan keputusan [7]. Sistem Pendukung Keputusan (DSS) adalah sistem komputer yang membantu pengambil keputusan memecahkan masalah dengan langsung menghubungi database tertentu dan program analisis [8]. Sistem Pendukung Keputusan adalah sistem komputer interaktif yang membantu pengambil keputusan menggunakan data dan model untuk memecahkan masalah tidak terstruktur dan semi terstruktur [9].

\section{Analytical Hierarchy Process (AHP)}

AHP adalah sebuah konsep untuk pembuatan keputusan berbasis multikriteria (kriteria yang banyak). Membandingkan standar (tingkat kepentingan) satu sama lain adalah inti dari konsep AHP, yang menetapkan keputusan atau keputusan yang menggabungkan prinsip-prinsip tujuan dan sasaran pembuatan keputusan [2]. AHP adalah pemodelan untuk membantu pola pikir manusia dalam mengambil suatu keputusan [10]. AHP adalah sebuah metode terstruktur untuk mengelola dan menganalisa keputusan-keputusan yang bersifat kompleks dengan konsep matematis dan fsikologi, metode AHP membantu dalam menentukan bobot prioritas setiap parameter yang menjadi acuan atau pertimbangan dalam melakukan pengambilan keputusan [11].

Dalam menyelesaikan permasalahan dengan AHP, ada beberapa prinsip yang harus dipahami sebagai berikut [12].

1. Membuat hierarki.

Sistem yang kompleks dapat dipahami dengan membaginya menjadi elemen-elemen bantu, menyusun elemenelemen tersebut secara berurutan, dan menggabungkannya atau mensintesisnya seperti pada Gambar 1. 


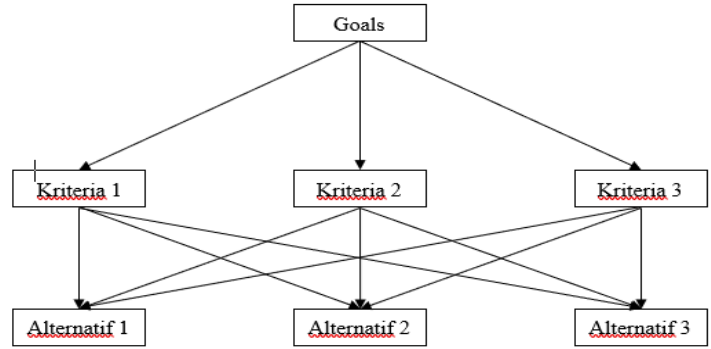

Gambar 1. Hierarki dalam AHP

(Sanyoto dkk, 2017)

2. Penilaian kriteria dan alternatif

Kriteria dan alternatif dilakukan dengan perbandingan berpasangan. Untuk banyak masalah, skala 1 sampai 9 adalah cara terbaik untuk mengungkapkan perasaan. Nilai dan signifikansi umpan balik positif dari pengukuran perbandingan dapat diukur dengan menggunakan tabel pengukuran seperti ditunjukkan pada Tabel 1.

Tabel 1. Tabel Analisis

\begin{tabular}{cl}
$\begin{array}{c}\text { Intensitas } \\
\text { Kepentingan }\end{array}$ & \multicolumn{1}{c}{ Keterangan } \\
\hline 1 & Kedua elemen sama pentingnya \\
\hline 3 & $\begin{array}{l}\text { Elemen yang satu sedikit lebih penting } \\
\text { dari pada elemen yang lainnya. }\end{array}$ \\
\hline 5 & $\begin{array}{l}\text { Elemen yang satu lebih penting dari } \\
\text { elemen yang lainnya. }\end{array}$ \\
\hline 7 & $\begin{array}{l}\text { Satu elemen jelas lebih mutlak penting } \\
\text { dari elemen lainnya. }\end{array}$ \\
\hline 9 & $\begin{array}{l}\text { Satu elemen mutlak penting dari elemen } \\
\text { lainnya }\end{array}$ \\
\hline Kebalikan & $\begin{array}{l}\text { Nilai-nilai antara dua pertimbangan } \\
\text { yang berdekatan }\end{array}$ \\
\hline $\begin{array}{l}\text { Jika aktivitas I mendapat satu angka } \\
\text { dibandingkan aktivitas I maka I } \\
\text { memiliki nilai kebalikan dibandingkan } \\
\text { aktivitas i. }\end{array}$ \\
\hline
\end{tabular}

Sumber: Kusrini, 2007

3. Synthesis of priority (menentukan prioritas)

Perbandingan berpasangan diperlukan untuk setiap pengukuran. Nilai perbandingan relatif dari setiap perubahan dapat disesuaikan berdasarkan keputusan yang telah ditentukan untuk menetapkan bobot dan kepentingan. Bobot dan nilai dihitung menggunakan matriks atau dengan menyelesaikan persamaan.

\section{Logical Consistency (Konsistensi Logis)}

Konsistensi memiliki dua makna. Pertama, kelompokkan objek-objek yang serupa sesuai dengan keseragaman dan relevansi. Kedua, berdasarkan tingkat hubungan antar objek menurut kriteria tertentu.

Prosedur atau langkah-langkah metode AHP sebagai berikut [13].

1. Mendefinisikan masalah, menentukan kebutuhan akan solusi, dan kemudian membuat daftar hierarki masalah yang dihadapi. Hirarki adalah kemampuan manusia untuk mengenali dan mengidentifikasi objek dan ide serta mengomunikasikan pengamatan. Untuk memperoleh pengetahuan terperinci, pikiran kita melakukan ini secara hierarkis, menempatkan realitas dalam konteks untuk mendapatkan pengetahuan yang terperinci, kemudian membaginya menjadi beberapa bagian.

2. Menentukan prioritas elemen

Langkah pertama dalam menentukan prioritas elemen adalah membuat matriks perbandingan pasangan. Matriks perbandingan berpasangan diisi menggunakan angka untuk menunjukkan kepentingan relatif dari suatu elemen terhadap elemen yang lainnya.

3. Sintesis

Keputusan untuk melakukan perbandingan berpasangan disintesis untuk memperoleh keseluruhan prioritas. 
4. Mengukur konsistensi

Mengetahui seberapa baik suatu hubungan ketika membuat keputusan adalah penting karena kita tidak ingin keputusan yang saling bertentangan. Hal-hal yang dilakukan dalam langkah ini adalah:

a. Hitung Consistency Index (CI) dengan rumus :

$\mathrm{CI}=(\lambda$ maks-n $) / \mathrm{n}-1$, Di mana $\mathrm{n}=$ banyaknya elemen

b. Hitung Rasio Konsistensi atau Consistency Ratio (CR) dengan rumus : $\mathrm{CR}=\mathrm{CI} / \mathrm{IR}$, Di mana $\mathrm{CR}=$ Consistency Ratio, $\quad \mathrm{CI}=$ Consistency Index, $\mathrm{IR}=$ Indeks Random Consistency.

c. Memeriksa konsistensi hirarki.

Jika nilainya lebih dari 10\%, maka penilaian data judgment harus diperbaiki. Namun jika rasio konsistensi (CI/IR) kurang atau sama dengan 0,1. maka hasil perhitungan bisa dinyatakan benar.

\section{METODE PENELITIAN}

\section{A. Tahapan Penelitian}

Adapun tahapan penelitian yang dilakukan dapat dilihat pada Gambar 2.

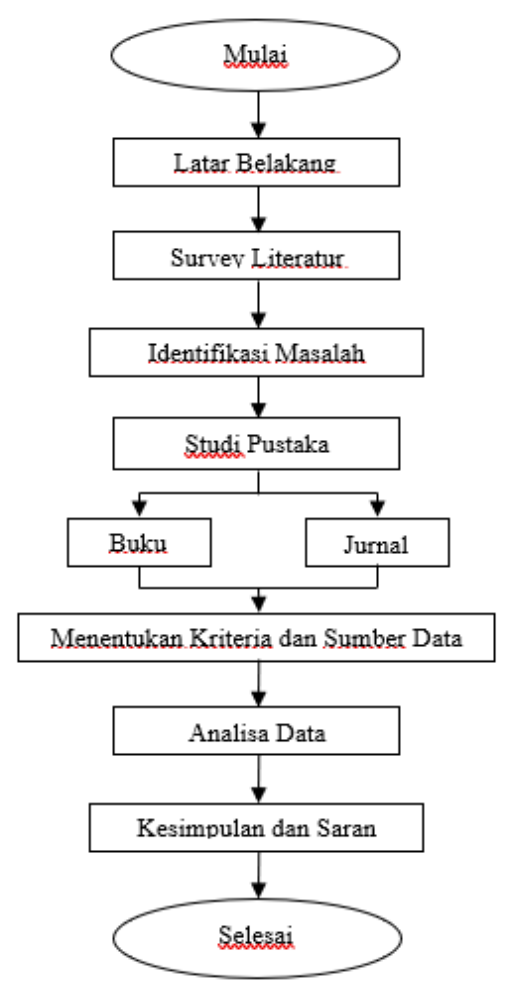

Gambar 2. Tahapan Penelitian (Briantama, 2020)

\section{B. Alat dan bahan penelitian}

Alat dan bahan yang digunakan dalam penelitian ini yaitu:

1. Literatur dari berbagai sumber seperti buku referensi, jurnal, dan internet browsing.

2. Kuesioner online dengan menggunakan fasilitas google form yang di dalamnya terdapat beberapa pertanyaan terkait pemilihan provider internet untuk memperoleh data yang dibutuhkan dalam penelitian ini.

\section{Instrumen Penelitian}

Instrumen penelitian adalah suatu alat yang digunakan untuk mengumpulkan data atau mengukur objek dari suatu variabel penelitian [14]. Adapun kisi-kisi kuesioner penelitian ini pada Tabel 2. 
Tabel 2. Kisi-Kisi Kuesioner

\begin{tabular}{|c|c|c|c|c|}
\hline Ne & Kriteria & $\begin{array}{c}\text { Penilaian } \\
\text { Kriteria }\end{array}$ & Hasil Ukur & $\begin{array}{l}\text { Skala } \\
\text { Ukur }\end{array}$ \\
\hline 1 & Harga & $\begin{array}{l}\text { Harga berlangganan paket } \\
\text { internet ynlimited per } \\
\text { bulan }\end{array}$ & $\begin{array}{l}\text { 1. Sama Penting } \\
\text { 3. Sedikit Lebih Penting } \\
\text { 5. Agak Lebih Penting } \\
\text { 7. Jauh Lebih Penting } \\
\text { 9. Mutlak Lebih Penting } \\
\text { 2,4,6,8 Nilai Antara Angka Diatas. }\end{array}$ & Ordinal \\
\hline 2 & Boudvisith & $\begin{array}{l}\text { Total Rogashwidth yang } \\
\text { didapat dalam paket } \\
\text { berlangganan internet } \\
\text { unlimited per bulan }\end{array}$ & $\begin{array}{l}\text { 1. Sama Penting } \\
\text { 3. Sedikit Lebih Penting } \\
\text { 5. Agak Lebih Penting } \\
\text { 7. Jauh Lebih Penting } \\
\text { 9. Mutlak Lebih Penting } \\
\text { 2,4,6,8 Nilai Antara Angka Diatas }\end{array}$ & Ordinal \\
\hline 3 & $\begin{array}{l}\text { Cakupan } \\
\text { Area } \\
\text { Jaringan }\end{array}$ & $\begin{array}{l}\text { Cakupan area jaringan } \\
\text { masing-masing penyedia } \\
\text { jasa internet }\end{array}$ & $\begin{array}{l}\text { 1. Sama Penting } \\
\text { 3. Sedikit Lebih Penting } \\
\text { 5. Agak Lebih Penting } \\
\text { 7. Jauh Lebih Penting } \\
\text { 9. Mutlak Lebih Penting } \\
\text { 2,4,6,8 Nilai Antara Angka Diatas. }\end{array}$ & Ordinal \\
\hline 4 & $\begin{array}{l}\text { Suppost } \\
\text { Helpdessk }\end{array}$ & $\begin{array}{l}\text { Kecepatan respon } \\
\text { operator helpdeskt dalam } \\
\text { menangani kendala pada } \\
\text { saat terjadi gangguan }\end{array}$ & $\begin{array}{l}\text { 1. Sama Penting } \\
\text { 3. Sedikit Lebih Penting } \\
\text { 5. Agak Lebih Penting } \\
\text { 7. Jauh Lebih Penting } \\
\text { 9. Mutlak Lebih Penting } \\
\text { 2,4,6,8 Nilai Antara Angka Diatas. }\end{array}$ & Ordinal \\
\hline
\end{tabular}

Sumber: Briantama, 2020

\section{Populasi dan Sampel}

Populasi dalam penelitian ini yaitu seluruh mahasiswa Universitas Nusa Mandiri Kampus Damai dari semester 7 hingga semester 9 yang berjumlah 540 mahasiswa. Perhitungan sampel dalam penelitian ini dengan menggunakan rumus slovin sebagai berikut :

$$
n=\frac{540}{1+540 \times(0,1)^{2}}=84,375=84
$$

Dengan begitu peneliti menjadikan 84 mahasiswa yang menggunakan koneksi internet wifi untuk mengakses perkuliahan online selama pandemi sebagai sampel atau responden pada penelitian ini.

\section{HASIL DAN PEMBAHASAN}

\section{A. Struktur Analytical Hierarchy Process}

Struktur hierarki Analytical Hierarchy Process (AHP) sistem pendukung keputusan dalam pemilihan provider internet untuk menunjang perkuliahan online saat pandemi Covid-19 ditunjukkan pada Gambar 3.

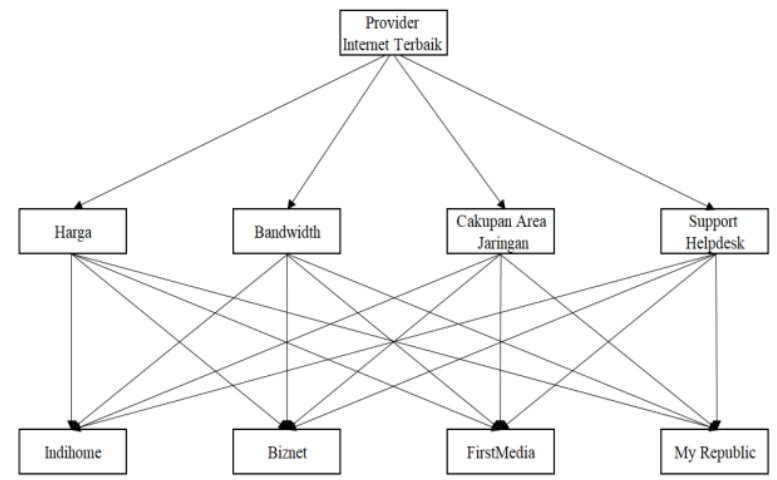

Gambar 3. Struktur Hierarki AHP

(Briantama, 2020)

\section{B. Perbandingan Berpasangan}

Pada tahap ini matrik perbandingan berpasangan diisi bilangan untuk membandingkan berbagai elemen terhadap elemen lain untuk menunjukan seberapa penting bobotnya. Dalam hal ini yang menjadi point perbandingan yaitu elemen dari kriteria dan alternatif secara berpasangan. Gambar 4 sampai dengan Gambar 8 menunjukkan perbandingan berpasangan.

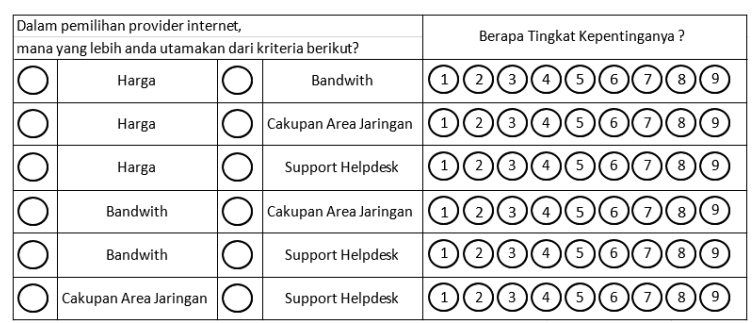

Gambar 4. Perbandingan Berpasangan Kriteria

(Briantama, 2020)

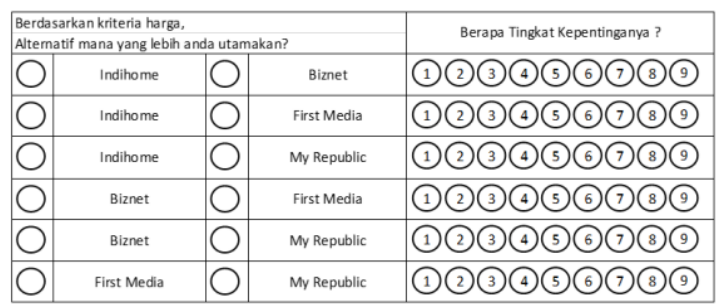

Gambar 5. Perbandingan Berpasangan Alternatif Harga

(Briantama, 2020) 


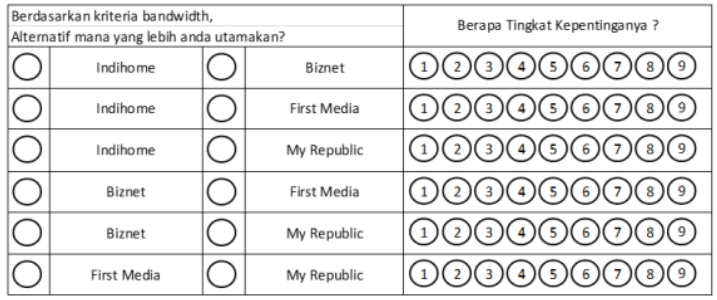

Gambar 6. Perbandingan Berpasangan

Alternatif Bandwith

(Briantama, 2020)

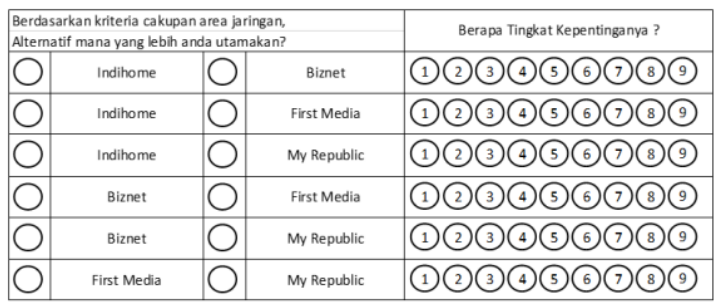

Gambar 7. Perbandingan Berpasangan Alternatif Cakupan Area Jaringan

(Briantama, 2020)

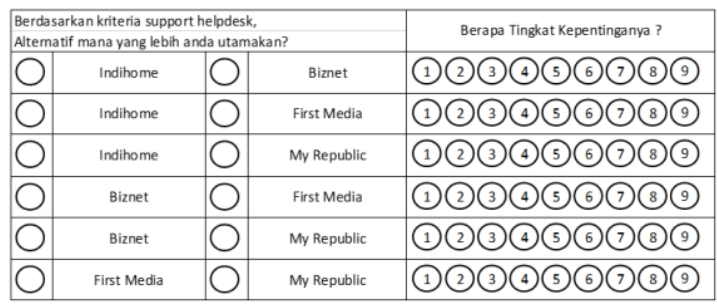

Gambar 8. Perbandingan Berpasangan

Alternatif Support Helpdesk

(Briantama, 2020)

Langkah selanjutnya adalah mencari rata-rata perbandingan masing-masing elemen dengan cara mengalikan semua elemen matriks perbandingan yang seletak kemudian di akar pangkat kan dengan banyaknya responden. Maka tabel perhitungannya dapat dilihat pada Tabel 3 sampai dengan Tabel 7.

Tabel 3. Perbandingan Rata-Rata Kriteria Utama

\begin{tabular}{lcccc}
\hline Kriteria & Harga & $\begin{array}{c}\text { Bandwidt } \\
\mathrm{h}\end{array}$ & $\begin{array}{c}\text { Cakupa } \\
\mathrm{n} \text { area } \\
\text { jaringa } \\
\mathrm{n}\end{array}$ & $\begin{array}{c}\text { Support } \\
\text { Helpdes } \\
\mathrm{k}\end{array}$ \\
\hline Harga & $\begin{array}{c}1,000 \\
0\end{array}$ & 0,7218 & 0,3682 & 0,5495 \\
\hline $\begin{array}{l}\text { Bandwidt } \\
\text { h }\end{array}$ & $\begin{array}{c}1,385 \\
5\end{array}$ & 1,0000 & 0,7634 & 1,4600 \\
\hline
\end{tabular}

\begin{tabular}{lcccc}
$\begin{array}{l}\text { Cakupan } \\
\text { area } \\
\text { jaringan }\end{array}$ & $\begin{array}{c}2,716 \\
2\end{array}$ & 1,3099 & 1,0000 & 4,0752 \\
$\begin{array}{l}\text { Support } \\
\begin{array}{l}\text { Helpdes } \\
\text { k }\end{array}\end{array}$ & $\begin{array}{c}1,819 \\
\text { Jumlah }\end{array}$ & 0,6849 & 0,2454 & 1,0000 \\
& 6 & 3,7166 & 2,3770 & 7,0847 \\
\hline
\end{tabular}

Sumber: Briantama, 2020

Tabel 4. Perbandingan Rata-Rata Kriteria Harga

\begin{tabular}{lcccc}
\hline Kriteria & $\begin{array}{c}\text { Indihom } \\
\mathrm{e}\end{array}$ & $\begin{array}{c}\text { Biz } \\
\text { net }\end{array}$ & $\begin{array}{c}\text { FirstMedi } \\
\mathrm{a}\end{array}$ & $\begin{array}{c}\text { My } \\
\text { Republi } \\
\mathrm{c}\end{array}$ \\
\hline Indihome & 1,0000 & $\begin{array}{c}1,84 \\
84\end{array}$ & 1,3374 & 1,3878 \\
\hline Biznet & 0,5410 & $\begin{array}{c}1,00 \\
00\end{array}$ & 0,9610 & 1,1630 \\
\hline FirstMedi & 0,7477 & 1.04 & 1,0000 & 1,7573 \\
a & & 06 & & \\
\hline My & 0,7206 & 0,85 & 0,5691 & 1,0000 \\
Republic & & 98 & & \\
\hline Total & 3.0093 & 4,74 & 3,8674 & 5,3081 \\
& & 89 & &
\end{tabular}

Sumber: Briantama, 2020

Tabel 5. Perbandingan Rata-Rata Kriteria Bandwith

\begin{tabular}{|c|c|c|c|c|}
\hline Kriteria & $\begin{array}{l}\text { Indiho } \\
\text { me }\end{array}$ & $\begin{array}{c}\text { Bizne } \\
\mathrm{t}\end{array}$ & $\begin{array}{l}\text { FirstMed } \\
\text { ia }\end{array}$ & $\begin{array}{l}\text { My } \\
\text { Republ } \\
\text { ic }\end{array}$ \\
\hline $\begin{array}{l}\text { Indihom } \\
\mathrm{e}\end{array}$ & 1,0000 & $\begin{array}{c}1,213 \\
5\end{array}$ & 1,3121 & 1,4979 \\
\hline Biznet & 0,8240 & $\begin{array}{c}1,000 \\
0\end{array}$ & 1,5071 & 1,3999 \\
\hline $\begin{array}{l}\text { FirstMed } \\
\text { ia }\end{array}$ & 0,7621 & $\begin{array}{c}0,663 \\
5\end{array}$ & 1,0000 & 1,7515 \\
\hline $\begin{array}{l}\text { My } \\
\text { Republic }\end{array}$ & 0,6676 & $\begin{array}{c}0,714 \\
4\end{array}$ & 0,5710 & 1,0000 \\
\hline Total & 3,2538 & $\begin{array}{c}3,591 \\
4\end{array}$ & 4,3902 & 5,6492 \\
\hline
\end{tabular}

Sumber: Briantama, 2020

Tabel 6. Perbandingan Rata-Rata Kriteria Cakupan Area Jaringan

\begin{tabular}{lcccc} 
Kriteria & $\begin{array}{c}\text { Indiho } \\
\text { me }\end{array}$ & $\begin{array}{c}\text { Bizne } \\
\mathrm{t}\end{array}$ & $\begin{array}{c}\text { FirstMed } \\
\text { ia }\end{array}$ & $\begin{array}{c}\text { My } \\
\text { Republ } \\
\text { ic }\end{array}$ \\
\hline $\begin{array}{l}\text { Indihom } \\
\text { e }\end{array}$ & 1,0000 & $\begin{array}{c}2,594 \\
0\end{array}$ & 2,3175 & 3,1622 \\
Biznet & 0,3855 & $\begin{array}{c}1,000 \\
0\end{array}$ & 1,2662 & 2,1009 \\
& & 0 &
\end{tabular}




\begin{tabular}{lcccc}
\hline $\begin{array}{l}\text { FirstMed } \\
\text { ia }\end{array}$ & 0,4315 & $\begin{array}{c}0,789 \\
8\end{array}$ & 1,0000 & 9,8279 \\
\hline My & 0,3142 & 0,476 & 0,1018 & 1,0000 \\
Republic & & 0 & & \\
\hline Total & 2,1333 & 4,859 & 4,6854 & 16,091 \\
& & 7 & & 0
\end{tabular}

Sumber: Briantama, 2020

Tabel 7. Perbandingan Rata-Rata Kriteria Support Helpdesk

\begin{tabular}{|c|c|c|c|c|}
\hline Kriteria & $\begin{array}{c}\text { Indihom } \\
\mathrm{e}\end{array}$ & $\begin{array}{c}\text { Bizne } \\
t\end{array}$ & $\begin{array}{c}\text { FirstMedi } \\
\mathrm{a}\end{array}$ & $\begin{array}{c}\text { My } \\
\text { Republi } \\
\text { c }\end{array}$ \\
\hline Indihome & 1,0000 & $\begin{array}{c}1,829 \\
3\end{array}$ & 1,7681 & 1,8674 \\
\hline Biznet & 0,5466 & $\begin{array}{c}1,000 \\
0\end{array}$ & 1,0198 & 1,5951 \\
\hline $\begin{array}{l}\text { FirstMedi } \\
\text { a }\end{array}$ & 0,5656 & $\begin{array}{c}0,980 \\
6\end{array}$ & 1,0000 & 2,2776 \\
\hline $\begin{array}{l}\text { My } \\
\text { Republic }\end{array}$ & 0,5355 & $\begin{array}{c}0,626 \\
9\end{array}$ & 0,4391 & 1,0000 \\
\hline Total & 2,6477 & $\begin{array}{c}4,436 \\
9\end{array}$ & 4,2270 & 6,7400 \\
\hline
\end{tabular}

Sumber: Briantama, 2020

\section{Sintesis Prioritas}

Setelah matriks perbandingan ditemukan, langkah selanjutnya adalah mencari eigen vector atau nilai rata-rata (local priority) dari tiap matriks perbandingan berpasangan. Pada setiap sintesis prioritas (Synthesis of priority), proses yang dilakukan sesuai matriks perbandingan yang telah dibuat sebelumnya. Proses sintesis prioritas dikerjakan sebanyak 5 kali, dapat dilihat pada Tabel 8 sampai dengan Tabel 12.

\section{Level 1 berdasarkan Kriteria Utama}

Tabel 8. Eigen Vector Kriteria Utama

\begin{tabular}{lccccc}
\hline Kriteria & $\begin{array}{c}\text { Harg } \\
\text { a }\end{array}$ & $\begin{array}{c}\text { Bandwi } \\
\text { dth }\end{array}$ & $\begin{array}{c}\text { Cakup } \\
\text { an } \\
\text { area } \\
\text { jaring } \\
\text { an }\end{array}$ & $\begin{array}{c}\text { Suppo } \\
\text { rt } \\
\text { Helpd } \\
\text { esk }\end{array}$ & $\begin{array}{c}\text { Eige } \\
\text { Vect } \\
\text { or }\end{array}$ \\
\hline Harga & 0,14 & 0,1942 & 0,154 & 0,0776 & 0,14 \\
& 45 & & 9 & & 28 \\
\hline Bandwi & 0,20 & 0,2691 & 0,321 & 0,2061 & 0,24 \\
dth & 02 & & 2 & & 91 \\
\hline \hline
\end{tabular}

\begin{tabular}{lccccc} 
Cakupa & 0,39 & 0,3524 & 0,420 & 0,575 & 0,43 \\
$\mathrm{n}$ area & 24 & & 7 & 2 & 52 \\
jaringa & & & & & \\
$\mathrm{n}$ & & & & & \\
\hline $\begin{array}{l}\text { Suppor } \\
\mathrm{t}\end{array}$ & 0,26 & 0,1843 & 0,103 & 0,141 & 0,17 \\
$\begin{array}{l}\text { Helpde } \\
\text { sk }\end{array}$ & & & 2 & 1 & 29 \\
& & & & \\
\hline & & Jumlah & & & 1,00 \\
& & & & 00 \\
\hline
\end{tabular}

Sumber: Briantama, 2020

Jadi urutan kriteria untuk pemilihan provider internet adalah:

1) Cakupan Area Jaringan

2) Bandwidth

3) Support Helpdesk

4) Harga

2. Level 2 berdasarkan Kriteria Harga

Tabel 9. Eigen Vector Kriteria Harga

\begin{tabular}{|c|c|c|c|c|c|}
\hline Harga & $\begin{array}{c}\text { Indi } \\
\text { ho } \\
\text { me }\end{array}$ & $\begin{array}{l}\text { Biz } \\
\text { net }\end{array}$ & $\begin{array}{c}\text { First } \\
\text { Medi } \\
\text { a }\end{array}$ & $\begin{array}{c}\text { My } \\
\text { Repu } \\
\text { blic }\end{array}$ & $\begin{array}{l}\text { Eigen } \\
\text { Vector }\end{array}$ \\
\hline Indiho & 0,33 & 0,38 & 0,345 & 0,261 & 0,3322 \\
\hline me & 23 & 92 & 8 & 5 & \\
\hline Biznet & $\begin{array}{c}0,17 \\
98\end{array}$ & $\begin{array}{c}0,21 \\
06\end{array}$ & $\begin{array}{c}0,248 \\
5\end{array}$ & $\begin{array}{c}0,219 \\
1\end{array}$ & 0,2145 \\
\hline $\begin{array}{l}\text { FirstM } \\
\text { edia }\end{array}$ & $\begin{array}{c}0,24 \\
85\end{array}$ & $\begin{array}{c}0,21 \\
91\end{array}$ & $\begin{array}{c}0,258 \\
6\end{array}$ & $\begin{array}{c}0,331 \\
1\end{array}$ & 0,2643 \\
\hline $\begin{array}{l}\text { My } \\
\text { Republ } \\
\text { ic }\end{array}$ & $\begin{array}{c}0,23 \\
98\end{array}$ & $\begin{array}{c}0,18 \\
11\end{array}$ & $\begin{array}{c}0,147 \\
1\end{array}$ & $\begin{array}{c}0,188 \\
4\end{array}$ & 0,1890 \\
\hline & & Jumla & & & 1.0000 \\
\hline
\end{tabular}

Sumber: Briantama, 2020

Jadi urutan kriteria Harga dengan alternatif untuk pemilihan provider internet adalah:

1) Indihome

2) FirstMedia

3) Biznet

4) My Republic

3. Level 2 berdasarkan Kriteria Bandwith 
Tabel 10. Eigen Vector Kriteria Bandwith Bandwi Indiho Bizn FirstMe My Eige dth me et dia $\begin{gathered}\text { Repub } \\ \text { lic } \\ \text { Vect }\end{gathered}$

\begin{tabular}{cccccc} 
& & & & & or \\
\hline Indiho & 0,3073 & 0,33 & 0,2989 & 0,265 & 0,30
\end{tabular}

\begin{tabular}{lccccc} 
me & & 79 & & 1 & 23 \\
\hline Biznet & 0,2533 & 0,27 & 0,3433 & 0,247 & 0,28
\end{tabular}

$\begin{array}{lllll} & 84 & 8 & 07\end{array}$

$\begin{array}{llllll}\text { FirstMe } & 0,2342 & 0,18 & 0,2278 & 0,310 & 0,23\end{array}$

$\begin{array}{lllll}\text { dia } & 48 & 0 & 92\end{array}$

$\begin{array}{llllll}\text { My } & 0,2052 & 0,19 & 0,1301 & 0,177 & 0,17\end{array}$

$\begin{array}{llll}\text { Republi } & 89 & 0 & 78\end{array}$

c

Jumlah

00

Sumber: Briantama, 2020

Jadi urutan kriteria Bandwidth dengan alternatif untuk pemilihan provider internet adalah:

1) Indihome

2) Biznet

3) FirstMedia

4) My Republic

4. Level 2 berdasarkan Kriteria Cakupan Area Jaringan

Tabel 11. Eigen Vector Kriteria Cakupan Area Jaringan

\begin{tabular}{|c|c|c|c|c|c|}
\hline $\begin{array}{l}\text { Cakupan } \\
\text { Area } \\
\text { Jaringan }\end{array}$ & $\begin{array}{c}\text { Indi } \\
\text { ho } \\
\text { me }\end{array}$ & $\begin{array}{l}\text { Biz } \\
\text { net }\end{array}$ & $\begin{array}{c}\text { FirstMe } \\
\text { dia }\end{array}$ & $\begin{array}{l}\text { My } \\
\text { Repub } \\
\text { lic }\end{array}$ & $\begin{array}{c}\text { Eige } \\
\mathrm{n} \\
\mathrm{Vec} \\
\text { tor }\end{array}$ \\
\hline $\begin{array}{l}\text { Indihom } \\
\mathrm{e}\end{array}$ & $\begin{array}{c}0,46 \\
88\end{array}$ & $\begin{array}{c}0,53 \\
38\end{array}$ & 0,4946 & $\begin{array}{c}0,196 \\
5\end{array}$ & $\begin{array}{c}0,42 \\
34\end{array}$ \\
\hline Biznet & $\begin{array}{c}0,18 \\
07\end{array}$ & $\begin{array}{c}0,20 \\
58\end{array}$ & 0,2702 & $\begin{array}{c}0,130 \\
6\end{array}$ & $\begin{array}{c}0,19 \\
68\end{array}$ \\
\hline $\begin{array}{l}\text { FirstMed } \\
\text { ia }\end{array}$ & $\begin{array}{c}0,20 \\
23\end{array}$ & $\begin{array}{c}0,16 \\
25\end{array}$ & 0,2134 & $\begin{array}{c}0,610 \\
8\end{array}$ & $\begin{array}{c}0,29 \\
72\end{array}$ \\
\hline $\begin{array}{l}\text { My } \\
\text { Republic }\end{array}$ & $\begin{array}{c}0,14 \\
82\end{array}$ & $\begin{array}{c}0,09 \\
79\end{array}$ & 0,0217 & $\begin{array}{c}0,062 \\
1\end{array}$ & $\begin{array}{c}0,08 \\
25\end{array}$ \\
\hline
\end{tabular}

Sumber: Briantama, 2020
Jadi urutan kriteria Cakupan Area Jaringan dengan alternatif untuk pemilihan provider internet adalah:

1) Indihome

2) FirstMedia

3) Biznet

4) My Republic

5. Level 2 berdasarkan Kriteria Support Helpdesk

Tabel 12. Eigen Vector Kriteria Support

\begin{tabular}{lccccc}
\multicolumn{7}{c}{ Helpdesk } \\
\hline $\begin{array}{l}\text { Suppor } \\
\mathrm{t}\end{array}$ & $\begin{array}{c}\text { Indiho } \\
\text { me }\end{array}$ & $\begin{array}{c}\text { Bizn } \\
\text { et }\end{array}$ & $\begin{array}{c}\text { FirstM } \\
\text { edia } \\
\text { sk }\end{array}$ & $\begin{array}{c}\text { My } \\
\text { Repu } \\
\text { blic }\end{array}$ & $\begin{array}{c}\text { Eige } \\
\mathrm{n} \\
\text { Vect } \\
\text { or }\end{array}$ \\
\hline $\begin{array}{l}\text { Indiho } \\
\text { me }\end{array}$ & $\begin{array}{c}0,377 \\
7\end{array}$ & $\begin{array}{c}0,41 \\
23\end{array}$ & 0,4183 & 0,277 & 0,37 \\
& & 1 & 13 \\
\hline Biznet & 0,206 & 0,22 & 0,2413 & 0,236 & 0,22 \\
& 5 & 54 & & 7 & 74 \\
\hline $\begin{array}{l}\text { FirstM } \\
\text { edia }\end{array}$ & 0,213 & 0,22 & 0,2366 & 0,337 & 0,25 \\
\hline My & 6 & 10 & & 9 & 23 \\
Republ & 0,202 & 0,14 & 0,1039 & 0,148 & 0,14 \\
ic & 3 & 13 & & 4 & 89 \\
\hline & & & & & \\
\hline
\end{tabular}

Sumber: Briantama, 2020

Jadi urutan kriteria Support Helpdesk dengan alternatif untuk pemilihan provider internet adalah:

1) Indihome

2) FirstMedia

3) Biznet

4) My Republic

D. Konsistensi (Consistency)

Hal pertama yang dilakukan pada tahap konsistensi adalah menentukan lambda maksimum, matriks perbandingam berpasangan dikalikan dengan eigen vector. Matriks perbandingan berpasangan yang 
digunakan adalah yang belum dinormalisasi.

Setelah proses konsistensi dilakukan, tahap selanjutnya adalah melakukan perhitungan untuk pengambilan keputusan. Langkah-langkahnya sebagai berikut:

1. Gabungan eigen vektor pada level 2 kriteria (level alternative) dikalikan dengan eigen vektor pada level 1 (level utama).

Tabel 13. Hasil Eigen Vector Keputusan

\begin{tabular}{lccc}
\hline \multicolumn{1}{c}{ Alternatif } & Nilai & Persen $\%$ & Peringkat \\
\hline Indihome & 0,3712 & $37 \%$ & 1 \\
\hline Biznet & 0,2255 & $23 \%$ & 3 \\
\hline FirstMedia & 0,2703 & $27 \%$ & 2 \\
\hline $\begin{array}{l}\text { My } \\
\text { Republic }\end{array}$ & 0,1329 & $13 \%$ & 4 \\
umber: Briantama, 2020
\end{tabular}

2. Hasil operasi perkalian tersebut disebut sebagai eigen vector keputusan, keputusan ditentukan oleh nilai yang mempunyai jumlah paling besar.

a) Indihome memiliki bobot prioritas tertinggi dengan nilai 0,3712 .

b) FirstMedia memiliki bobot prioritas tertinggi ke-dua dengan nilai 0,2703.

c) Biznet memiliki bobot prioritas tertinggi ke-tiga dengan nilai 0,2255.

d) My Republic memiliki bobot prioritas tertinggi ke-empat dengan nilai 0,1329 .

Jika digambarkan dalam bentuk grafik maka dapat dilihat jumlah presentasenya dapat dilihat pada Gambar 9.

\section{Grafik Eigen Vector Keputusan}

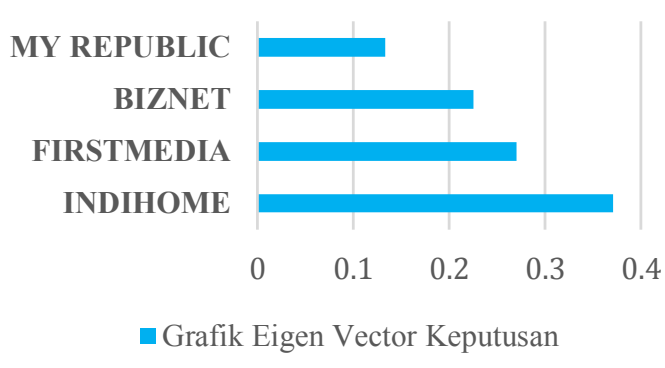

Gambar 9. Grafik Eigen Vector

Keputusan

(Briantama, 2020)

Setelah melihat grafik eigen vector diatas, maka dapat disimpulkan hasil analisa data yang menghasilkan indihome menjadi provider internet peringkat 1 yang paling banyak dipilih oleh responden dengan nilai 0,3712 presentase sebanyak $37 \%$. Firstmedia mendapat peringkat ke 2 dengan nilai 0,2703 presentase $27 \%$. Biznet mendapat peringkat ke 3 dengan nilai 0,2255 presentase $23 \%$, sedangkan My Republic mendapat peringkat ke 4 dengan nilai 0,1329 presentase $13 \%$.

\section{KESIMPULAN}

Dapat disimpulkan beberapa hal mengenai Sistem Pendukung Keputusan dalam Pemilihan Provider Internet untuk Menunjang Perkuliahan Online saat Pandemi Covid-19 yaitu:

a. Penelitian ini dapat memberikan rekomendasi bagi mahasiswa untuk menentukan atau memilih provider internet sebagai penunjang kegiatan kuliah online di masa pandemi.

b. Berdasarkan perhitungan Analytical Hierarchy Process, diperoleh prioritas kriteria yang paling penting dalam pemilihan provider internet adalah Harga, Bandwidth, Cakupan Area 
Jaringan serta Support Helpdesk dan yang menjadi prioritas pemilihan provider internet yaitu Cakupan Area Jaringan.

c. Hasil akhir dari perhitungan dijelaskan bahwa provider internet Indihome mendapatkan nilai 0,3712 dengan tingkat presentase $37 \%$, FirstMedia mendapatkan nilai 0,2703 dengan tingkat presentase $27 \%$, Biznet mendapatkan nilai 0,2255 dengan tingkat presentase $23 \%$, dan My Republic mendapatkan nilai 0,1329 dengan tingkat presentase 13\%. Hal ini menunjukan bahwa Indihome sebagai penyedia layanan internet lebih unggul dari alternatif lainnya. Dengan kata lain, Indihome lebih memenuhi kriteria pemilihan provider internet sebagai penunjang kegiatan kuliah online.

\section{DAFTAR PUSTAKA}

[1] A. Munthafa and H. Mubarok, "Penerapan Metode Analytical Hierarchy Process Dalam Sistem Pendukung Keputusan Penentuan Mahasiswa Berprestasi," J. Siliwangi, vol. 3, no. 2, pp. 192-201, 2017.

[2] M. I. Dzulhaq, A. Sidik, and D. A. Ulhaq, "Sistem Pendukung Keputusan Untuk Membandingkan Marketplace Terbaik Dengan Menggunakan Metode AHP Dan AHP," Acad. J. Comput. Sci. Res., vol. 1, no. 1, pp. 13-22, 2019.

[3] P. Utami and A. Mubarak, "MODEL PENGASUHAN ANAK TERKAIT PENGGUNAAN INTERNET DI ASIA," Pros. Nas. Psikol., vol. 2, pp. 1-9, 2018.

[4] I. Dahanum, Mesran, and T. Zebua, "Sistem Pendukung Keputusan Pemilihan Internet Service Provider Menerapkan Metode Elimination and Choice Translation Reality ( Electre )," Konf. Nas. Teknol. Inf. dan Komput., vol. I, no. 1, pp. 248-255, 2017.

[5] J. Sulistiono, "Implementasi Promethe II dalam Pemilihan Layanan Internet Service Provider pada PT Sinar Kreasindo," Semin. Nas. Teknol. Komput. Sains, pp. 559-570, 2019.

[6] W. Komputer, Cara Mudah Membangun Jaringan Komputer \& Internet. MediaKita, 2010.

[7] D. Indriani and A. I. Warnilah, "Sistem Informasi Hafalan Terbaik Dalam Munaqosah Tahfizhul Qur'an Menggunakan Metode Ahp," EVOLUSI - J. Sains dan Manaj., vol. 7, no. 1, pp. 1-11, 2019.

[8] N. B. Lingga and H. Hasugian, "Penerapan Metode Analytical Hierarchy Process (Ahp) Dan Simple Additive Weighting (Saw) Dalam Sistem Penunjang Keputusan Pemilihan Guru Terbaik Studi Kasus : Sma Negeri 63 Jakarta," J. Idealis, vol. 1, no. 3, pp. 396-403, 2018.

[9] A. Wanto et al., Sistem Pendukung Keputusan: Metode \& Implementasi. Yayasan Kita Menulis, 2020.

[10] T. Gundara and S. Anggraeni, "Pemilihan Program Penjurusan Pelajaran Seni SD Al-Fath Cirendeu Dengan Metode Analytic Hierarchy Process (AHP), ” J. Ilm. Ilk. - Ilmu Komput. Inform., vol. 3, no. 1, 2020.

[11] H. Wadi, Sistem Pendukung Keputusan Metode Analytic Hierarchy Process dengan PHP/MySQL : Studi Kasus Penentuan Prioritas Usulan Kegiatan Musrenbang. TURIDA Publisher.

[12] G. P. Sanyoto, R. I. Handayani, and 
E. Widanengsih, "Sistem Pendukung Keputusan Pemilihan Laptop Untuk Kebutuhan Operasional Dengan Metode Ahp ( Studi Kasus :," J. Pilar Nusa Mandiri Vol.13, No. 2., vol. 13, no. 2, pp. 167-174, 2017.

[13] Z. Azhar and M. Handayani, "ANALISIS PEMILIHAN PERUMAHAN KPR MENGGUNAKAN METODE AHP," Semin. Nas. R. (SENAR)., vol. 9986, no. September, 2018.

[14] F. Yusup, "Uji Validitas dan Reliabilitas Instrumen Penelitian Kuantitatif," J. Tarb. J. Ilm. Kependidikan, vol. 7, no. 1, pp. 1723, 2018. 